\title{
Kandungan Klorofil dan Karotenoid Daun Salam (Syzigium polyanthum (Wight) Walp.) pada Umur yang Berbeda
}

\author{
Chlorophylls and Carotenoid Content of Indonesian Bay Leaf \\ (Syzigium polyanthym (Wight) Walp.) at Different Ages
}

\author{
Abdul Khafid*, Sri Widodo Agung Suedy, Yulita Nurchayati \\ Program Studi Biologi Fakultas Sains dan Matematika Universitas Diponegoro Semarang \\ *Email : abdul.khafid1711@gmail.com
}

Diterima 7 Maret 2021 / Disetujui 26 April 2021

\begin{abstract}
ABSTRAK
Pohon salam (Syzygium polyanthum (Wight) Walp.) merupakan salah satu tumbuhan yang daunnya sering dimanfaatkan di Indonesia sebagai penyedap rasa dan obat-obatan tradisional. Daun salam umumnya dimanfaatkan dalam kondisi segar. Pemanfaatan daun segar tersebut dilakukan berdasar umur daun, yang berkaitan dengan kandungan bahan aktifnya. Penelitian ini bertujuan untuk mengetahui kandungan pigmen klorofil dan karotenoid daun salam pada umur yang berbeda. Penelitian menggunakan Rancangan Acak Lengkap, sampel daun diambil dari urutan daun yang berbeda berdasarkan letak duduk daun yaitu urut dari daun paling ujung (muda) merupakan daun ke-1, ke-3, ke-5, dan daun ke-7. Ulangan sebanyak 3 kali dari tangkai pohon yang berbeda. Parameter yang diamati adalah kandungan klorofil-a, klorofil-b, klorofil total dan karotenoid yang diukur secara spektrofotometri. Data dianalisis menggunakan ANOVA dilanjutkan dengan DMRT. Hasil penelitian menunjukkan bahwa kandungan pigmen klorofil dan karotenoid meningkat hingga puncak kedewasaan daun dan akan menurun setelahnya karena senescence. Kandungan klorofil-a tertinggi pada daun ke-3, sementara klorofil-b, klorofil total dan karotenoid tertinggi pada daun ke-5.
\end{abstract}

Kata kunci : penyedap, urutan daun, spektrofotometri, umur daun

\begin{abstract}
Indonesian bay leaf (Syzygium polyanthum (Wight) Walp.) is a plant whose leaves are used in Indonesia as flavoring and medicine. The use of leaves is based on the age of the leaves, generally used at fresh condition, which is related to the bioactive compound content. The study aims to determine the difference in chlorophyll and carotenoid content of Indonesian bay leaves at different ages. The result of this study is to provide information about the difference of chlorophyll content (a, b, totally) and carotenoid pigments in bay leaves of different ages. The study used a completely randomized design, leaf samples were taken based on the leaf sits, namely the order of the leaves at the very end (young) which was the 1st, 3rd, 5th, and 7th. Repeat 3 times from different tree stalks. The parameters observed were chlorophyll-a, chlorophyll-b, total chlorophyll, and carotenoids content which were measured spectrophotometrically. Data were analyzed using ANOVA followed by DMRT. The results showed chlorophyll and carotenoid pigments increases with increasing leaves age until the peak of leaf maturity, then declines because of senescence. The highest chlorophyll-a content was in the 3rd leaf, while the highest chlorophyll-b, total chlorophyll, and carotenoids in the 5th leaf.
\end{abstract}

Keywords : flavoring, leaf sequence, spectrophotometry, leaf age 


\section{PENDAHULUAN}

Salam (Syzygium polyanthum (Wight) Walp.) merupakan salah satu tumbuhan yang sering dimanfaatkan oleh masyarakat di berbagai daerah di Indonesia. Daun salam digunakan sebagai penyedap rasa, menambah aroma, memberi warna maupun maupun meningkatkan cita rasa makanan, Daun salam juga sering digunakan sebagai bahan obat-obatan tradisional. Pemanfaatan tumbuhan sebagai bumbu maupun untuk obat sebagian besar berhubungan dengan kandungan metabolit sekundernya khususnya essensial oil atau minyak atsiri. Daun salam berkhasiat sebagai obat sakit perut, menghentikan buang air besar yang berlebihan, mengatasi asam urat, stroke, kolesterol tinggi, melancarkan peredaran darah, radang lambung, gatal gatal dan diabetes (Wartini, dkk. 2007; Widyawati et al, 2012; Patel, et al., 2012; Harismah, 2017). Berbagai kandungan senyawa bioaktif terkandung di daun salam, antara lain flavonoid, saponin, triterpenoid, polifenol, alkaloid, tanin dan minyak atsiri. Tanin, flavonoid dan minyak atsiri yang bermanfaat sebagai antibakteri, flavonoid juga mampu menghambat kadar kolestrol (Giri, 2008; Kusumaningrum dkk., 2013; Rahayuningsih, 2014; Wiryawan, 2017), sementara etnis Batak juga memanfaatkan Syzygium polyanthum sebagai salah satu sumber buah (Anggraeni, 2013).

Daun merupakan organ tumbuhan yang memegang peranan penting. Daun salam berwarna hijau ketika masih dalam keadaan segar, disebabkan kandungan klorofil yang merupakan pigmen utama yang terdapat dalam membran tilakoid. Klorofil memiliki fungsi sebagai molekul yang berperan penting dalam fotosintesis. Selain klorofil, daun juga mengandung karotenoid yang merupakan pigmen pemberi warna kuning sampai jingga. Kandungan kimia yang terdapat dalam suatu tumbuhan tidak terlepas dari tahap pertumbuhan dan perkembangan tumbuhan tersebut (Sumenda, dkk., 2011), juga spesies tumbuhan maupun habitat lingkungan hidupnya (Kurniawan, dkk., 2010). Klorofil merupakan komponen penting dari kloroplas, dan kandungan klorofil positif berkorelasi dengan laju fotosintesis (Li et al., 2006). Kandungan klorofil tinggi dalam daun meningkatkan kapasitas tanaman dalam melakukan fotosintesis (Setiawati dkk., 2016). Selain dipengaruhi oleh faktor nutrisi, gen dan cahaya, kandungan pigmen pada daun juga dipengaruhi oleh usia daun. Menurut penelitian Lefsrud et al. (2007) pada daun yang masih muda biasa terlihat berwarna pucat. Hal ini dikarenakan jumlah kloroplas yang terbentuk masih terbatas. Ketika daun sudah mulai berkembang dan semakin besar ukurannya, pembentukan pigmen semakin tinggi, yang berguna untuk membantu proses penyediaan energi untuk fotosintesis. Penelitian Procházková et al. (2009) menunjukan pada daun yang sudah sangat tua, kandungan pigmen akan menurun dikarenakan terjadinya degradasi pigmen akibat dari proses senescence atau penuaan. Sedangkan penelitian Ikhsanti, et al. (2019) pada daun jambu Malabar (Syzygium jambos (L.) Alston.) menunjukkan bahwa semakin tinggi tahapan perkembangan daun, semakin tinggi pula klorofil-a, klorofil-b, klorofil total, karotenoid, total fenol, dan aktivitas antioksidannya.

Fotosintesis di daun diibaratkan sebagai "pabrik" utama dalam proses metabolisme primer yang hasilnya berguna bagi pertumbuhan serta perkembangan tumbuhan, maupun metabolisme sekunder yang berguna dalam membantu tumbuhan beradaptasi pada kondisi habitat lingkungannya yang dinamis. Penelitian tentang kandungan pigmen klorofil dan karotenoid pada daun salam perlu dilakukan. Kajian ini menjadi pelengkap dari uji terhadap kandungan bioaktif yang telah banyak dilakukan, karena kandungan metabolit baik primer maupun sekunder tumbuhan sangat dipengaruhi oleh proses fotosintesis yang terjadi di organ daun, sementara pada proses fotosintesis dipengaruhi kandungan pigmen fotosintetik pada daunnya. Tujuan dari penelitian ini yaitu untuk mengetahui kandungan klorofil-a, klorofil-b dan klorofil total serta karotenoid pada daun salam dengan umur yang berbeda.

\section{METODE PENELITIAN}

Penelitian ini dilaksanakan bulan Agustus 2020, bertempat di Laboratorium Biologi Struktur dan Fungsi Tumbuhan (BSFT) Departemen Biologi, Fakultas Sains dan Matematika Universitas 
Diponegoro. Bahan yang digunakan pada penelitian ini yaitu sampel daun tanaman salam Syzygium polyanthum (Wight) Walp.) yang diperoleh dari Kelurahan Kedungpane, Kecamatan Mijen, Kota Semarang, Aseton $80 \%$ dan kertas saring. Alat yang digunakan pada penelitian ini yaitu mortar, gelas ukur, corong, timbangan dan spektrofotometer UV Vis

\section{Analisis kandungan klorofil dan karotenoid}

Pengambilan sampel dilakukan dengan memilih daun pada tingkat umur yang berbeda berdasarkan letak duduk daun yaitu urut dari daun paling ujung (muda) merupakan daun Ke-1, Ke-3, $\mathrm{Ke}-5$, dan daun Ke-7. Tiap umur daun diambil 3 ulangan dari cabang/batang yang berbeda namun masih dalam satu pohon yang sama. Cara kerja: diambil daun salam sebanyak $0,1 \mathrm{~g}$ kemudian dihaluskan dengan mortar. Sampel yang sudah dihaluskan diekstraksi dengan $10 \mathrm{~mL}$ aseton $80 \%$, diaduk merata hingga klorofil dan karotenoid larut. Ekstrak tersebut disaring menggunakan kertas saring. Filtrat ditempatkan dalam cuvet untuk kemudian diukur nilai absorbansinya dengan spektrofotometer UV VIS pada panjang gelombang 480, 645, 646 dan $663 \mathrm{~nm}$ untuk menguji kandungan klorofil dan karotenoid (Hendry \& Grime, 1993). Setelah didapat nilai absorbansi, kandungan klorofil dihitung dengan menggunakan rumus sebagai berikut :

$$
\begin{aligned}
& \text { Klorofil a }(\mathrm{mg} / \mathrm{g})= \\
& ((12,7 \times \mathrm{A} 663)-(2,69 \times \mathrm{A} 645)) \times 10^{-1}
\end{aligned}
$$

Klorofil b $(\mathrm{mg} / \mathrm{g})=$

$((22,9 \times \mathrm{A} 645)-(4,68 \times \mathrm{A} 663)) \times 10^{-1}$

Klorofil total $(\mathrm{mg} / \mathrm{g})=$

$((8,02 \times \mathrm{A} 663)+(20,2 \times \mathrm{A} 645)) \times 10^{-1}$

Karotenoid $(\mu \mathrm{mol} / \mathrm{g})=$

$\underline{[(A 480+(0,114 \times A 663))-(0,638 \times A 645)] V \times 10^{3}}$ $112,5 x W$

(Hendry \& Grime, 1993)

Keterangan :

A480 = absorbansi pada panjang gelombang $480 \mathrm{~nm}$, A645 = absorbansi pada panjang gelombang $645 \mathrm{~nm}$,
A646 = absorbansi pada panjang gelombang $646 \mathrm{~nm}$, A663 = absorbansi pada panjang gelombang $663 \mathrm{~nm}, \mathrm{~V}$ $=$ volume ekstrak $(\mathrm{mL}), \mathrm{W}=$ berat sampel $(\mathrm{g})$.

\section{HASIL DAN PEMBAHASAN}

Hasil uji ANOVA menunjukkan adanya perbedaan nyata antar perlakuan, kemudian uji lanjut DMRT menunjukkan adanya perbedaan nyata pada daun urutan yang paling muda (daun ke1) dengan daun yang lebih tua (daun ke-3, 5 dan 7) seperti yang terlihat pada Tabel 1. Terjadinya perbedaan kandungan klorofil antara daun ke-1 dengan daun ke-3, 5 dan 7 ini berhubungan dengan tingkat perkembangan daun. Daun ke-1 merupakan daun yang letaknya berada di paling ujung dan merupakan daun yang paling muda umurnya dan warnanya masih hijau kecoklatan (Gambar 2.). Kandungan klorofil yang rendah pada daun termuda ini disebabkan oleh klorofil belum banyak terbentuk, sehingga akan berwarna sedikit kehijauan, berbeda dengan daun berumur lebih dewasa yang lebih tampak berwarna hijau. Menurut Sumenda, dkk (2011) pada daun yang masih muda, klorofil belum terbentuk, melainkan masih berupa protoklorofil. Setelah terjadi transformasi protoklorofil menjadi klorofil, daun akan menjadi berwarna hijau.

Klorofil merupakan molekul pigmen yang memberikan wana hijau pada tumbuhan, alga dan cyanobacteria (Inanc, 2011).. Klorofil berperan dalam mengubah energi cahaya dari sinar matahari menjadi energi kimiawi melalui penyerapan energi, mentransfer energi tereksitasi ke pusat reaksi (Chen, 2014). Klorofil juga memiliki manfaat dalam bidang kesehatan. Klorofil yang terkandung dalam daun memiliki manfaat sebagai anti-oksidan, antiperadangan, dan zat yang dapat menyembuhkan luka (Mishra et al., 2011)

Kandungan klorofil pada daun urutan ke-3, ke-5 dan ke-7 tidak menunjukkan perbedaan yang signifikan, namun terdapat kecenderungan peningkatan terutama pada daun ke-3 dan ke-5 (Tabel 1). Tingginya kandungan klorofil pada daun ke-3 sampai ke-7 dibanding dengan daun ke-1 menunjukkan umur daun yang telah memasuki fase pendewasaan. Daun yang telah dewasa secara fisiologis ditandai dengan tingginya kandungan 
klorofil. Hal ini sesuai dengan pernyataan Setiawati dkk. (2016) bahwa ketika daun bertambah tua, maka kadar klorofil akan semakin meningkat hingga puncak perkembangan. Dhami et al. (2018) menyatakan bahwa pada daun yang paling dewasa, ukuran dan jumlah sel akan meningkat. Hal ini juga akan berpengaruh pada jumlah kloroplas, sehingga pigmen yang dikandungnya akan semakin banyak. Jumlah pigmen yang tinggi ini mendukung untuk meningkatkan kemampuan daun untuk melakukan fotosintesis.

Tabel 1. Kandungan klorofil-a, klorofil-b dan klorofil total serta karotenoid daun salam (Syzygium polyanthum (Wight) Walp.) pada umur yang berbeda

\begin{tabular}{ccccc}
\hline $\begin{array}{c}\text { Umur daun } \\
(\text { Urutan })\end{array}$ & $\begin{array}{c}\text { Kadar Klorofil-a } \\
(\mathrm{mg} / \mathrm{g})\end{array}$ & $\begin{array}{c}\text { Kadar Klorofil-b } \\
(\mathrm{mg} / \mathrm{g})\end{array}$ & $\begin{array}{c}\text { Kadar Klorofil } \\
\text { Total }(\mathrm{mg} / \mathrm{g})\end{array}$ & $\begin{array}{c}\text { Kadar Karotenoid } \\
(\mu \mathrm{mol} / \mathrm{g})\end{array}$ \\
\hline 1 & $1,449^{\mathrm{b}}$ & $0,658^{\mathrm{d}}$ & $2,106^{\mathrm{f}}$ & $56,069^{\mathrm{h}}$ \\
3 & $2,827^{\mathrm{a}}$ & $1,893^{\mathrm{c}}$ & $4,719^{\mathrm{e}}$ & $117,609^{\mathrm{g}}$ \\
5 & $2,604^{\mathrm{a}}$ & $2,181^{\mathrm{c}}$ & $4,784^{\mathrm{e}}$ & $103,471^{\mathrm{g}}$ \\
7 & $2,785^{\mathrm{a}}$ & $1,622^{\mathrm{c}}$ & $4,407^{\mathrm{e}}$ & $102,360^{\mathrm{g}}$ \\
\hline
\end{tabular}

Keterangan : Angka yang diikuti huruf yang sama pada satu kolom yang sama menunjukkan hasil yang tidak berbeda nyata berdasarkan uji DMRT pada signifikansi $95 \%(\alpha=5 \%)$

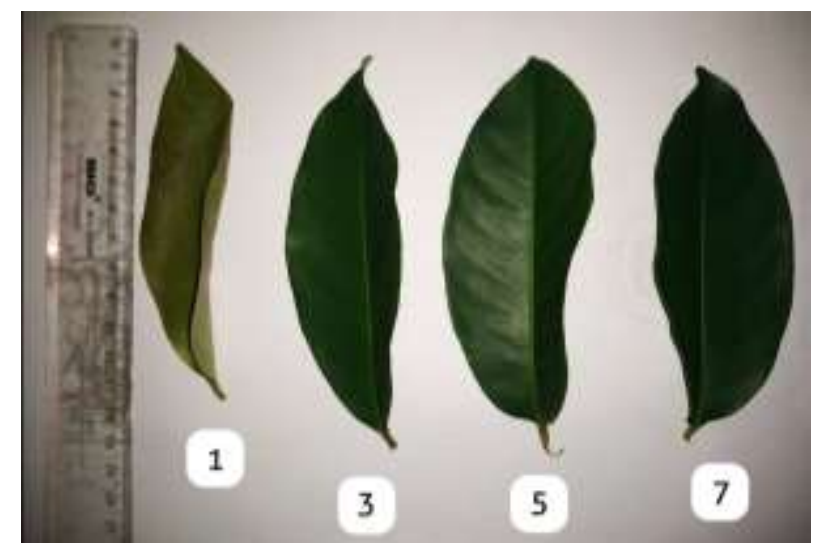

Gambar 1. Daun salam (Syzygium polyanthum (Wight) Walp.) dengan urutan ke-1, 3, 5 dan 7 dari ujung batang

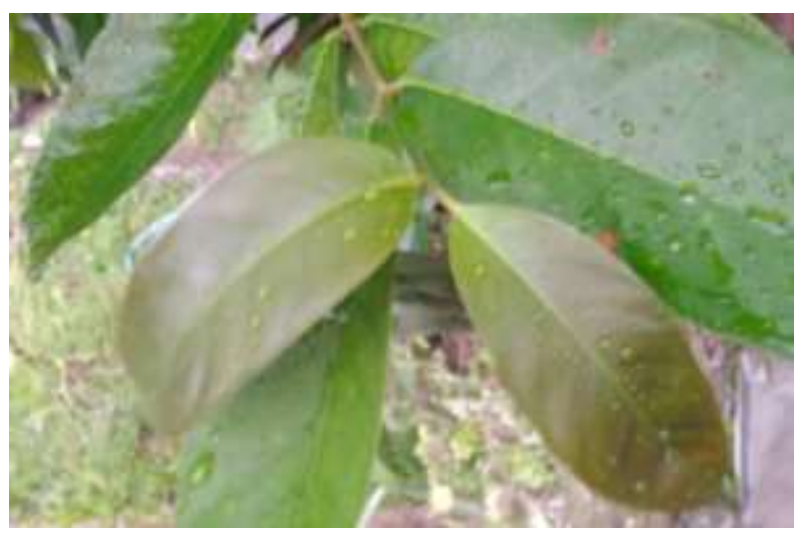

Gambar 2. Daun salam (Syzygium polyanthum (Wight) Walp.) urutan 1 dari ujung batang yang masih berwarna hijau kecoklatan 
Setelah daun mengalami puncak kedewasaan yang ditandai dengan kadar klorofil yang tinggi seperti pada daun ke-3 dan ke-5, akan terjadi penurunan kadar klorofil ketika daun bertambah tua seperti yang diperlihatkan pada daun Ke-7. Kejadian ini disebabkan oleh kerusakan klorofil pada daun akibat proses senescence. Procházková et al. (2009) menyatakan bahwa berkurangnya kadar klorofil pada daun yang lebih tua merupakan pertanda bahwa terjadinya proses senescence pada daun. Senescence adalah suatu proses aktif penuaan pada daun. Pada daun yang mengalami senescence, metabolit pada daun akan didegradasi, kemudian disalurkan kepada jaringan lain yang lebih muda yang masih aktif berkembang.

Pada Tabel 1., kandungan karotenoid pada daun urutan ke-1 menunjukkan rata-rata kandungan yang berbeda nyata dibanding daun pada urutan ke3, 5 dan 7 dengan kandungan karotenoid hampir dua kali lipatnya dari daun ke-1. Kandungan karotenoid yang rendah pada daun termuda (urutan ke-1) mengindikasikan bahwa perkembangan daun yang muda berlangsung cepat tetapi belum diikuti dengan perkembangan plastida, baik kloroplas maupun kromoplas. Karotenoid merupakan pigmen yang disintesis dalam plastida sel tumbuhan. Pada Spermatophyta, terdapat berbagai jenis karotenoid yang terbagi menjadi sub-kelompok karoten dan xantofil. Jalur biosintesisnya menggunakan jalur asam mevalonate yang menggunakan substrat awal asetil KoA (Dewick, 2002). Asetil Ko-A merupakan senyawa hasil respirasi dari tahap glikolisis yang akan melanjutkan jalur biosintesis menuju berbagai asam amino melalui siklus Krebs (Hopkins, 2000). Metabolisme primer dari tumbuhan tersebut akan menghasilkan sejumlah metabolit primer untuk membangun sel-sel baru. Pada daun yang masih muda, metabolit primer diutamakan untuk membentuk protoplasma dan dinding sel, Hal ini menyebabkan jalur pembentukan metabolit sekunder termasuk karotenoid belum berlangsung secara optimal.

Hasil ini berbeda dengan penelitian yang dilakukan oleh Dhami et al. (2018) yang menunjukkan bahwa daun Arabidopsis yang masih muda memiliki kandungan karotenoid yang lebih tinggi dibandung daun yang lebih tua. Muthoharoh dan Dahlia (2012) juga melaporkan penelitian bahwa pada daun sirih hijau (Piper betle L.) dan sirih merah (Piper crocatum Ruiz \& Pav.) pada urutan ke-3 merupakan daun yang memiliki kandungan karotenoid yang lebih tinggi dibanding daun urutan ke-6 dan ke-8. Rendahnya kandungan karotenoid pada daun salam urutan ke-1 ini disebabkan karena belum memasuki fase dewasa secara fisiologis, sehingga jumlah sel dan kloroplas yang terbentuk masih lebih sedikit. Menurut Lefsrud et al. (2007) penelitiannya tentang kandungan karotenoid pada tanaman kale (Brassica oleracea L. var. acephala) pada daun yang belum dewasa, kandungan karotenoidnya sangat rendah apabila dibandingkan dengan daun yang sudah dewasa.

Kandungan pigmen karotenoid daun salam pada daun Ke-3, Ke-5 dan Ke-7 tidak ada perbedaan nyata, namun pada daun ke-3 cenderung lebih tinggi dibanding urutan daun yang lain. Hal terjadi karena berkaitan dengan umur daun dan selaras dengan kandungan klorofilnya. Daun urutan ke-3 mengandung klorofil yang meningkat dibanding daun urutan ke-1. Klorofil memerlukan pigmen asesoris karotenoid yang akan mengoptimalkan pengikatan foton dari cahaya matahari dalam reaksi terang fotosintesis. Hal ini sesuai dengan pernyataan Hashimoto et al. (2016) bahwa karotenoid menyerap spektrum cahaya matahari pada bagian hijau-biru, meneruskan ke klorofil sehingga dapat memperluas rentang penyerapan cahaya untuk membantu klorofil dalam fotosintesis

Kandungan karotenoid pada daun urutan ke5 dan ke-7 cenderung lebih rendah dibanding urutan daun ke-3. Selain karena memasuki fase penuaan, rendahnya kandungan karotenoid pada daun ke-5 dan ke-7 juga disebabkan karena peran klorofil yang diduga lebih dominan daripada karotenoid pada umur daun yang dewasa. Procházková et al. (2009) menyatakan bahwa kandungan karotenoid menurun dengan semakin bertambahnya usia daun. Guiboileau, et al. (2010) menyatakan bahwa senescence pada daun merupakan suatu proses untuk mendaur ulang materi sel agar dapat digunakan kembali sebagai nutrisi bagi jaringan yang masih berkembang. Senescence juga berfungsi untuk mengatur penggunaan nutrisi agar lebih efisien untuk proses 
pembentukan organ tumbuhan yang baru dan untuk menjaga kesehatan tumbuhan itu sendiri. Pada penelitian ini, pengukuran dilakukan pada kandungan karotenoid total, tidak komponen/jenis karotenoid yang ada seperti karoten, xantofil maupun xantofil.

\section{KESIMPULAN}

Berdasarkan dari hasil penelitian dapat disimpulkan bahwa kandungan pigmen klorofil baik klorofil-a, klorofil-b, klorofil total dan karotenoid meningkat seiring pertambahan umur daun salam (Syzigium polyanthym (Wight) Walp.) hingga pada usia puncak kedewasaan. Setelah melewati puncak kedewasaan, kandungan klorofil dan karotenoid akan menurun karena pengaruh dari senescence.

\section{DAFTAR PUSTAKA}

Anggraeni, R. 2013. Etnobotani Masyarakat Subetnis Batak Toba di Desa Peadungdung,Sumatera Utara. Skripsi. Departemen Biologi, Fakultas MIPA USU.

Badan POM RI. 2008. Taksonomi Koleksi Tanaman Obat Kebun Tanaman Obat Citeureup. Jakarta: Badan Pengawas Obat dan Makanan Republik Indonesia.

Chen M. 2014. Chlorophyll Modifications and Their Spectral Extension in Oxygenic Photosynthesis. Annual Review of Biochemistry 83: 317-340.

Croft, H., and Chen, J. M. 2017. Leaf Pigment Content. Reference Module in Earth Systems and Environmental Sciences. Oxford: Elsevier Inc.

Dewick, P.P. 2002. Medicinal Natural Products, A Biosynthetic Approach, John Wiley and Sons, Ltd., School of Pharmaceutical Sciences University of Nottingham, UK. P.149.

Dhami, N., Tissue, D. T., and Cazzonelli, C. I. 2018. Leaf-age Dependent Response of Carotenoid Accumulation to Elevated $\mathrm{CO}_{2}$ in Arabidopsis. Archives of Biochemistry and Biophysics (647) : 67-75.
Giri, L. N. 2008. Potensi Antioksidasi Daun Salam: Kajian In Vivo pada Tikus Hiperkolesterolemia dan Hiperglikemia. [Skripsi]. Fakultas MIPA Institut Pertanian Bogor, Bogor.

Guiboileau, A., Sormani, R., Meyer, C., and Masclaux-Daubresse, C. 2010. Senescence and Death of Plant Organs: Nutrient Recycling And Developmental Regulation. Comptes Rendus Biologies, 333(4), 382-391.

Harismah, K. 2017. Pemanfaatan Daun Salam (Eugenia polyantha) Sebagai Obat Herbal dan Rempah Penyedap Makanan. Warta LPM 19(2) : 110-118.

Hashimoto, H., Uragami, C., and Cogdell, R. J. 2016. Carotenoids and Photosynthesis. Subcellular Biochemistry, 79, 111-139.

Hendry, G. A. F., and Grime, J. P. 1993. Methods on Comparative Plant Ecology. A Laboratory Manual. London: Chapman and Hill.

Inanc A. L. 2011. Chlorophyll : Structural Properties, Health Benefits and its Occurrence in Virgin Olive Oils. Akadem Gida, 9(2):26-32.

Kurniawan, M., Izzati, M., dan Nurchayati, Y. 2010. Kandungan Klorofil, Karotenoid, dan Vitamin C pada Beberapa Spesies Tumbuhan Akuatik. Buletin Anatomi Fisiologi 18(1) : 28-40.

Kusumaningrum, A., Widiyaningrum, P., dan Mubarok, I. 2013. Penurunan total bakteri daging ayam dengan perlakuan perendaman infusa daun salam (Syzygium polyanthum). Jurnal Mipa 36(1) : .

Lefsrud, M., Kopsell, D., Wenzel, A., and Sheehan, J. 2007. Changes in kale (Brassica oleracea L. var. acephala) Carotenoid And Chlorophyll Pigment Concentrations During Leaf Ontogeny. Scientia Horticulturae, 112(2), 136-141.

Li, R., P. Guo, M. Baum, S. Grando, and S. Ceccarelli. 2006. Evaluation of Chlorophyll 
Content and Fluorescence Parameters as Indicators of Drought Tolerance in Barley. Agricultural Sciences in China. 5(10): 751757.

Mishra, V. K., Bacheti, R. K., Husen, A., Le, H., and Salcedo, A. E. 2011. Medicinal Uses of Chlorophyll: $\quad A \quad$ Critical Overview. Chlorophyll: Structure, Function and Medicinal Uses. Edited by ES Hua Le. Nova Science Publishers, Inc., Hauppauge, New York, 177-196.

Muthoharoh, L. dan Dahlia. 2011. Analisis Berbagai Pigmen Daun Sirih Hijau (Piper betle L.) dan Sirih Merah (Piper crocatum Ruiz \& Pav.) Berdasarkan Umur Fisiologis Daun. [Skripsi]. Fakultas MIPA Universitas Negeri Malang, Malang.

Patel, D., Prasad, S., Kumar, R., and Hemalatha, S. 2012. An Overview On Antidiabetic Medicinal Plants Having Insulin Mimetic Property. Asian Pac. J. Trop. Biomed. 4: 320-330

Procházková, D., Haisel, D., and Wilhelmová, N. 2009. Content Of Carotenoids During Ageing and Senescence of Tobacco Leaves with Genetically Modulated Life-Span. Photosynthetica, 47(3), 409.

Rahayuningsih, H. M. 2014. Perbedaan Pengaruh antara Ekstrak dan Rebusan Daun Salam (Eugenia polyantha) dalam Pencegahan Peningkatan Kadar Kolesterol Total pada Tikus Sprague Dawley. Journal of Nutrition College, 3(1) : 142-149.

Setiawati, T., Saragih, I. A., Nurzaman, M., dan Mutaqin, A. Z. 2016. Analisis Kadar Klorofil dan Luas Daun Lampeni (Ardisia humilis Thunberg) pada Tingkat Perkembangan yang Berbeda di Cagar Alam Pangandaran. Prosiding Seminar Nasional MIPA 2016 25(1): 122-126.

Sumenda, L., Rampe, L H., dan Mantiri, F. R., 2011. Analisa Kandungan Klorofil Daun Mangga (Mangifera indica L.) pada Tingkat Perkembangan Daun yang Berbeda. Bioslogos 1 (1), 20-24
Wartini, N.M., Harijono, Susanto, T.,Retnowati, R., dan Yunianta. 2007. Pengaruh Proses Curing Terhadap Komposisi Daun Salam (Eugenia polyantha Wight.), Profil Komponen Dan Tingkat Kesukaan Ekstrak Flavor Hasil Distilasi-Ekstraksi Simultan. Jurnal Teknologi Pertanian 8(1): 10-18.

Widyawati, T., Purnawan, W.W., Yam, M.F., Asmawi, M.Z., dan Ahmad, M. 2012. The Use of Medicinal Herbs Among Diabetic Patients in Health Community Centre Sering, Medan, Indonesia. in: Proceedings of the MSPP2012 Conference, Penang, Malaysia, 19-20 May 2012; pp. 113-114.

Wiryawan, K. G. 2007. Peningkatan Performa Ayam Broiler dengan Suplementasi Daun Salam [Syzygium polyanthum (Wight) Walp] Sebagai Antibakteri Escherichia coli. Media Peternakan, 30(1) : 55-62 